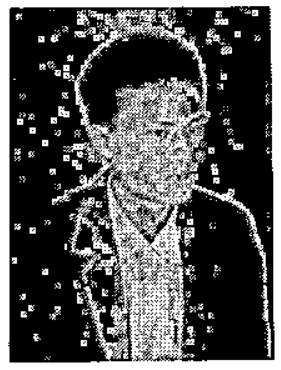

\title{
URGENSI ANTISIPASI \\ YURIDIS ATAS \\ MENGEJALANYA SISTEM \\ PERBANKAN ISLAM
}

O1.eh I gus Hivyanta

\begin{abstract}
Mulai bermunculannya Bank Islam di negeri kita memang menarik paling tidak karena dianggap sudah menjadi keharusan sejarah. Namun bisa jadi hal ini menjadi problem bila tidak segera ada aturan yuridisnya. Agus Triyanta, mencoba menawarkan jalan keluar.
\end{abstract}

$\mathrm{D}$ iantara gejala yang muncul akhir-akhir ini, yang nampaknya akan cukup memberikan nuasa baru bagi tahuntahun pada era PJPT II mendatang adalah tumbuh berkembangnya usaha perbankan dengan sistem Islam (non bunga), yang menampakkan masa depan yang prospektif.

Bagi dunia internasional, sebenarnya meruyaknya sistem perbankan Islam bukanlah suatu gejala baru. Masalah ini sudah mulai populer sejak sekitar dua dasawarsa yang lalu.

Perbankan Islam, ungkap Khursyid Ahmad --tokoh yang cukup intens mempopulerkan sistem perbankan Islam-bukanlah suatu masalah teoritis belaka. Lebih dari 12 bank nasional dan internasional --menurut informasi terakhir saat ini di dunia ada 32 bank Islam ${ }^{1}$-- yang bebas binga dewa- sa ini telah beroperasi dengan gemilang di berbagai belahan dunia termasuk di Barat. ${ }^{2)}$

Di Indonesia, dengan mulai beroperasinya BMI pada tanggal 1 Mei 1992 setelah sebelumnya mendapat izin prinsip, Surat Menteri Keuangan RI no. 1223/MK.013/1991, Izin usaha berupa Keputusan Menteri Keuangan RI no. 430/KMK;013/1992 tanggal 24 April 1992,3) menyusul kemudian berdirinya BPR-BPR Syari'ah (Bank Perkreditan Rakyat) di

1) H. Karnaen Perwataatmadja, MPA, Drs., dan M. Syafi'i Antonio, M.Ec., H, Apa dan Bagaimana Bank Islam, Dana Bhakti Wakaf, cet-1, Yogyakarta, 1992, hal. 55.

2) Pengantar Khursyid Ahmad dalam: Muhammad Najatullah Sdiqqi, Bank Islam, Pustaka, Bandung, 1984, hal. v.

3) Karnaen, Op.Cit., hal. 85. 
berbagai kota yang bisa dilegalkan dengan UU Perbankan BAB III pasal 5 yang menyatakan tentang adanya dua jenis bank; Bank Umum dan BPR, juga pasal 13 butir c yang menyatakan bahwa usaha BPR meliputi; c. menyediakan pembiayaan bagi nasabah berdasarkan prinsip bagi hasil sesuai dengan ketentuan yang ditetapkan Peraturan Pemerintah. 4)

Melihat hal itu, maka perlu ada antisipasi dengan perangkat perundang-undangan, mengingat, kinerja, prinsip operasional, serta herbagai produk dan hal-hal yang berkaitan dengan sistem perbankan Islam sangat berbeda dengan sistem perbankan konvensional, dan sudah barang tentu hal ini akan membawa implikasi, khusunya terhadap sosio yuridis.

\section{Mengapa BMI Mesti Ada ?}

Bank berkembang sejalan dengan kehidupan manusia. Di zaman modem seperti sekarang ini, kebutuhan akan perbankan nyaris tidak bisa dipisahkan dari pola produksi-konsumsi yang dilakukan manusia. Dalam beberapa tahun terakhir ini, di Indónesia, usaha perbankan mengalami pèrkembangan yang sangat pesat.

Pakto 1980 yang digulirkan pemerintah, pada hakekatnya adalah serangkaian kebijaksanaan baru dari Menkeu Ekuien (Radius Prawiro), yang merupakan paket deregulasi di bidang keuangan moneter dan perbankan (KMP), yang di umumkan pada tanggal 28 Oktober $1988,{ }^{5)}$ dengan sengaja telah memberikan angin untuk berdiri dan berkembanganya perbankan. Berbagai perusahaan perbankan bermunculan dengan menawarkan paket-paket layanan yang variatif dan menggiurkan. Merebaknya usaha perbankan, sebenamya suatu hal yang logis saja bila kita berangkat dari asumsibahwa kian mustahil untuk memisahkan afiliasi kehidupan masyarakat dengan dunia perbankan. Manusia banyak mendapatkan kemudahan, yang hal itu sulit, atau bahkan tidak bisa didapatkan pada institusi yang lain.

Meski demikian, perbankan modern --dengan sistem konvensional (interest system)-- bukannya tidak pemah menimbulkan dampak. Bank-bank modem dengan konvensionalitas sistemnya, ternyata telah mencuatkan suatu perdebatan dan pertentangan baru, terkhusus di kalangan umat Islam.

Dari itulah, maka sebenarnya kejenuhan akan perbankan konvensional bagi semnetara manusia memang beralasan; dan bagi umat Islam khususnya, kejenuhan itu bisa diabsahkan dengan dua pembenaran:

\section{a. Riba}

Riba merupakan alasan teologis kenapa umat Islam mesti mencari terobosan baru di sela-sela perbankan konvensional. Larangan riba, pada hakekatnya bukanlah monopoli Islam saja. Dua agama besar samawi lainya pun, yaitu Yahudi dan Nasrani, keduannya juga melarang praktek riba. ${ }^{6)}$ Dalam Injil kita tidak terlalu sulit untuk menemukan ayatlarangan praktik riba. ${ }^{7)}$ Bahkan, Dr. Muhammad Hamidullah pun menyatakan, tidak mungkin ada orang yang dengan senang hati. mau membayar bunga, mereka mau membayar bunga (riba) karena harus melakukan konsekuensi dari uang yang mereka pinjam. ${ }^{8)}$ Sehingga, kalau mau diangkat secara fair, yang merasa berkepentingnan dengan perbankan sistem bungaa bukan hanya umat Islam saja. Penulis

4) UU No. 7 Th 1992 Tentang Perbankan, CV. Mini Jaya Abadi, Jakarta, 1992

5) Widjanarto, Hukum dan Ketentuan Perbankan di Indonesia, Cet. 2, Grafiti, Jakarta, 1993, hal. 29-32.

6) Karnaen Op.Cit., hal. 13.

7) Misalnya; dalam Perjanjian Lama, Kitab Exodus (Keluaran) Pasal 22 ayat 25, serta Kitab Deuterenomy (Ulangan) Pasal 23 ayat 9.

8) Muhammad Hamidullah, DR., Introduction to Islam, th, IIFSO, cet. 2, 1970, hal. 151. 
tidak tahu persis, apakah berangkat dari asumsi yang demikian ini ataukah tidak, yang jelas bahwa Dr. Ganner Thorland Jepsen dan Mr. Erick Trolle Schulzt (keduanya non Muslim) telah menjadi managing Directors di Islamic Bak International of Demark. ${ }^{9)}$

Namun bagaimanapun jug; Islamlah yangpaling kentara dan vokal mengadakan penentangan secara frontal terhadap riba, yang menurut interpretasi M. Abdul Mannan, penentangan itu itu disebabkan karena sifat kezaliman dari riba tersebut. ${ }^{10)}$ Disamping itu, riba sendiri telah menimbulkan resiko yang cukup berbahaya, yang nanti akan bisa kita lihat pada perbandingan keuntungan sistem perbankan konvensional yang menyndarkan nadi keberlangsungan pada sistem bunga.

Dengan begitu tegasnya, Al-Qur'an melarang praktek riba. ${ }^{11)}$ Dan dari formulasi para ulama, larangan riba dalam Al-Qur'an aalah riba nasi'ah. Meski ada beberapa macam riba, ialah riba Fadhl (pertukaran barang sejenis dengan kadar/takaran yang berbeda), dan riba Nasi'ah (ialah apabila oarang yang berhutang menambah pembayarannya sebagai ganti waktu perpanjangan pembayarannya kembali), bahkan ada yang menambahkan riba Qardh (suatu manfaat atau tingkat kelebihan tertentu yang diayaratkan terhadap yang berhutang), ${ }^{12}$ ) namun yang secara mutlak disepakati sebagai riba yang dilarang dan dinyatakan sebagai suatu bentuk riba yang dimaksud al-Qur'an dan terjadi di zaman Jahiliyah adalah riba Nasi'ah. ${ }^{13)}$

Tentang persamaanya dengan rente, atau bunga bank (interest) di zaman modern, para ulama lebih menyepakai kesamaannya. Keduanya merupakan ekses dari modal yang dipinjam, menyebut riba dengan nama bunga pun juga tidak mengubah sifatnya. ${ }^{14)}$ Bahkan A. Hassan, --ulama Persis yang di Indonesia dikenal paling longgar dalam merespon bunga bank--, tetap saja memberikan batasan dengan kriteria bahwa bunga yang diperbolehkan adalah; yang tidak ganda berganda. Tidak membawa kepada ganda berganda -ini mengacu pada QS. 3:130 yang mengisyaratkan kriteria adh'afan mudha'afan-- tidak mahal, sekiranya orang yang meminjam dapat berusaha dengan uang itu dengan tidak menanggung kerugian, serta pinjaman itu hendaknya untuk kepentingan produktif. ${ }^{15)}$ Dan upaya sebagian ahli atau sebagian umat (intelektual) Islam untuk melegalkan bunga bank modem, menurut Nejatullah Siddiqi, mendapatkan penolakan dan cemoohan hampir diseluruh dunia. ${ }^{16)}$ dari sisi lain, penentangan Islam terhadap riba (bunga bank), ungkap Joseph Schacht, justru merupakan suatu bentuk elemen yang mampu menunjukan koherensi dan kelengkapan sebuah doktrin. ${ }^{17)}$ Sehingga, sikap penerimaan umat Islam (ulama) terhadap aabank sistem riba sehubungan dengan kumustahilan untuk melepaskan kaitannya

9) Karnaen, Op.Cit., hal. 51.

10) Muhammad Abdul Mannan, MA., Ph.D., Teori dan Praktek Ekonomi Islam, terjemah, Drs. M. Nastangin, cet. 1, PT. Dana Bhakti Wakaf, Yogyakarta, 1993.

11) Q.S. 2:275, 3:130, 4:29.

12) Karnaen, Op.Cit., hal. 9-11, lihat juga: A. Chotib, Drs., Bank Dalom Islam, Cet. 1, Bulan Bintang, Jakarta, 1962, hal. 23.

13) A. Chotib, Drs., Ibid, hal. 25-26, Mannan, Op.Cit. hal. 118-119, Houstma, dkk.' ed., First Encyclopedia of Islam (Leiden/New York/Kobenhavn/ Koln: E.J. Brillst, 1987) Vol. IV, hal. 1148-1149.

14) Mannan, Op.Cit., hal. 120-121.

15) A. Chotib, Drs., Op.Cit., hal. 74-76.

16) Muhammad Farid Wadji, Dairah al-Ma'arif al-Qam al-Isyrin, Beint: al-Maktab al-Ilmiyyah al-Jadidah, tt, hal. I88-189, M. Nejatullah Siddiqi, Op.Cit., hal. xiv

17) Yoseph Schacht, An Introduction To Islamic Law, tt, Oxford University Press, 1964, Kelengkapan yuridis al-Qur'qn juga ditekankan dalam; Muhammad Iqbal, Rahasia-Rahasia Pribadi, terjemah Bahrun Rangkuti - Arif Husain BALLB, Pustaka Islam, tt, Jakarta, hal. 41.

18) A. Chotib, Drs., Op.Cit., hal. 100-101 
dengan kehidupan, adalah karena keterpaksaan saja. ${ }^{8)}$ Tentu saja, keterpaksan ini bila memang, belum atau tidak ada lembaga perbankan bebas bunga yang bisa dijadikan alterbatif selain bank konvensional. Dari sini kita makin bisa memahami antusiasitas Islam untuk mewujudkan suatu bank Islam.

\section{b. Perlu Alterbatif}

Terlepas dari perdekatan teologis tersebut diatas, perkembangan kehidupan manusia memang senantiasa menuntut adanya improvisasi dan diversifikasi munuju yang lebih baik dan sesedikit mungkin mengandung resiko. Sophistikasi kehidupan telah memberikan kecenderungan (trend) untuk membuat terobosan-terobosan dan modus alternatif yang baru, termasuk dalam dunia perbankan. Menyadari kondisi dunia dengan sistem perbankan yang ada, yang oleh Nejatullah diungkapkan dengan:

Tingginya inflasi di samping tingkat pengangguran yang tinggi, dengan tingkat bunga yang kadang-kadang melebihi duapuluh persen, dan sistem pembayaran internasional yang terasa berat akibat penjejalan pinjamanpinjaman, keadaan tersebut semakin tidak dapat dipertahankan. ${ }^{19)}$

Maka wajarlah bila kehadiran perbankan dengan sistem baru sangat dinantikan. Cukup beralasan bila dikatakan bahwa permasalah perbankan non riba bukan saja merupakan sebuah upaya penghindaran umat terhadap sistem bunga, namun sudah merupakan sebuah altematif baru dalam dunia perbankan.

\section{Karakteristik BMI}

BMI (Bank MUamalat Indonesia), adalah usaha perbankan yang pertama kalinya beroperasi di Indonesia dan menerapkan sistem tanpa bunga dengan penawaran prduk yang relatif lengakap (lebih lengkap dari pada
BPR Syari'ah). Bank ini memang masih merupakan fenomena yang baru di Indonesia, meski bagi banyak negara Islam tertentu, atau bahkan juga negara Barat; bank Islam sudah bukan suatu hal yang asing lagi. Pantas saja bila kemunculannya sempat membuat banyak orang bertanya-tanya tentang apa dan bagaimana bank Islam secara realitis, karena selama ini di Indonesia permasalahan bank Islam hanya berhenti pada dataran diskusi dan dialog.

Sebagai suatu bank Islam, karaateristiknya akan nampak minimal dalam dua faktor :

\section{a. Prinsip Operasional}

Bank Islam (BMI), pada prinsipnya adalah sebuah bank dengan sistem bebas bunga, sama sekali berbeda dengan bank konvensional yang memakai sistem bunga. Dan dalam mekanismenya, diterapkan apa yang menjadi ajaran sayari'ah yaitu berdasarkan prinsip (syirkah) mitra usaha yang telah diakui dunia. ${ }^{20)}$ (Dan menurut penulis, ini identik dengan yang dimaksudkan oleh $\dot{M}$. Umar Chapra dengan profitsharing). ${ }^{21)}$

Prinsip dasar syirkah itu sendiri terjabarkan dalam beberapa variasi sebagaimana dibawah ini $:^{22)}$

- Mudharabah; yaitu tenaga kerja dan pemilik modal bergabung bersama-sama sebagai mitra usaha untuk kerja.

- Murabbahah; yaitu para klien bank memberi suatu komoditimenurut rincian tertentu dan menghendaki agar bank

19) M. Nejatullan, Op.Cit., hal xvii

20) Mannan, Op.Cit., hal. 167-168.

21) Artikel M. Umar Chapra dalam: Khursyid Ahmad - Zafar Ishaq Ansari, ed., Islamic Perspective, London: The Islamic Foundation, UK, 1979, hal. 213.

22) Ibid, hal. 167-168., Ahmad Abu al-Fathi, Kitab al-Mu'amalat, cet. 1, al-Basfur, Mesir, 1913, Juz II, hal. 487-490. Uraian panjang lebar juga dapat dilihat pada: Ibn al-Rusyd, Bidayah al-Mujtahid, tt, Dar al-Fikr, tt, hal. 191-192, atau Abu Bakar al-Jazairiy, Minhaj al-Muslim, hal. Fi al-Syirkah. 
mengirimkannya kepada mereka berdasarkan' imbuhan harga tertentu menurut persetujuan mula antara kedua pihak.

- Musyarakah; yaitu baik bank maupun klien menjadi mitra usaha dengan menyumbang modal dalam berbagai tingkat dan mencapai kata sepakat atas suatu rasio laba di muka untuk suatu waktu tertentu.

Dari konsep dasar syirkah dalam Islam ini, BMI mengaplikasikannya dengan varian di bawah ini : ${ }^{23}$

- Sistem Bagi Hasil: ialah sistem yang meliputi tata cara pembagian hasil usaha antara penyedia dana dengan pengelola dana. Ini dapat terjadi antara bank dengan penyimpan dana, maupun antara bank dengan nasabiah penerima dana (identik dengan Mudharabah dan Musyarakah).

- Sistem Jual Beli dengan Margin Keuntungan; ialah dengan menerapkan tata cara jual beli, di mana bank mengangkat nasabah sebagai agen bank dan nasabah dalam kapasitasnya sebagai agen bank melakukan pembelian atas nama bank, kemudian bank akan bertindak sebagai penjual akan menjual barang tersebut kepada nasabah dengan harga sejumlah harga beli ditambah keuntungan bagi bank (margin/mark-up).

- Sistem Fee (Jasa); ialah meliputi seluruh layanan non- pembiayaan yang di berikan oleh bank.

\section{b. Produk-Produk dari BMI}

Sebagai suatu bank Islam, BMI menawarkan paket-paket produk sebagai berikut:

- Produk penghimpunan dana BMI yang terdiri dari : $:^{24)}$

1. Giro Wadia'ah yaitu simpanan penarikannya yang dapat dilakukan setiapsaat dengan menggunakan cek, surat pembayaran lain, atau dengan cara 2.
Tabungan Mudharabah; yaitu, dana yang disimpan nasabah akan dikelola bank untuk memperoleh keuntungan, yang pembagiannya berdasarkan kesepakatan bersama. Karena produk ini memungkinkan adanya mutasi, sehingga perlu perhitungan saldo rata-rata.

3. Deposito Investasi Mudharabah ; yaitu simpanan yang penarikannya hanya dapat dilakukan pada waktu tertentu sesuai dengan perjanjian antara penyimpan bank.

4. Tabungan Haji Mudharabah; yaitu simpanan pihak ketiga yang penarikannya dilakukan pada saat nasabah akan menunaikan ibadah haji, atau kondisi tertentu sesuai perjanjian.

5. Tabungan Qurban; yaitu simpanan pihak ketiga yang dihimpunkan untuk ibadah Qurban, dengan penarikan pada saat akan melaksanakan iabadah qurban, atau sesuai perjanjian antara keduanya.

- Sedangkan Produk Penyaluran Dana BMI adalah :25)

1. Pembiayaan Mudharabah; yaitu bank dapat menyediakan pembiayaan modal investasi atau modal kerjasepenuhnya, sedangkan nasabah menyediakan usaha dan manajemen.

2. Pembiayaan Murabahah; yaitu pembiayaan untuk barang lokal maupun intemasional (mirip kredit modal kerja dari bank konvensional). Bank mendapat keuntungan dari harga barang yang dinaikkan (harga jual baru yang terdiri dari harga beli ditambah margin keuntungan)

3.

23) Karnaen, Op.Cit, hal. 88. 48-49.

24) Ibid., hal 89 , juga Wijanarto, Op.Cit, hal.

25) Ibid, hal. 49-51, Karnaen, Op.Cit., hal. 89-90. 
Pembiayan Bai' Bitsaman Ajil; yaitu pembiayaan untuk pembelian barang dengan cicilan, dengan ketentuan yangseperti no. 2 diatas.

4. Pembiayaan al-Qardhul Hasan; ialah pinjaman lunak bagi pengusaha kecil yang benar-benar kekurangan modal. Nasabah tidak perlu membagi keuntungan pada bank, tapi hanya membayar beaya administrasi saja, yang merupakan beaya real yang tak bisa dihindari untuk terjadinya suatu kontrak. (Biasanya untuk pinjaman konsumtif keterpaksaan dimasukkan kesini). ${ }^{26)}$

5. Pembiayaan Musyarakah; yaitu pembiayaan sebagian dari modal usaha keseluruhan, yang mana pihak bank dapat dilihatkan dalam proses manajemen.

6. Produk Jasa lainnya meliputi; Jasa Penerbitan L/C - Jasa Inkaso, Jasa Transfer - Bank Garansi.

\section{Prospek dan Implikasi Sosialnya}

Adalah merupakan sebuah tantangan bagi urnat Islam untuk menumbuhkembangkan sistem perbankan Islam. Para pendisain tata ekonomi Islampun -- dalam artian orang yang dengan penuh antusias berusaha menerjemah-kan (meng-applied-kan) konsep Qur'an dan Sunnah dalam kehidupan berekonomi-- sebe- narnya juga mempunyai beben yang sangat berat. Mereka ditantang untuk tidak membuat kegagalan, yang nantinya dapat menurunkan kredibilitas sistem non bunga ini. ${ }^{27}$ Sehingga patut diperhatikan apa yang ditekankan oleh Khursyid Ahmad bahwa tantangan besar yang dihadapi dunia Islam adalah tantangan untuk menyusun kembali tat perekonomiannya ... ${ }^{28}$

Harus disadari memang, bahwa ada kelemahan-kelemahan tertentu dalam bank Islam, namun kelemahan itu menjadi tidak begitu berarti dan tidak krusial bila dikomparasikan dengan keuntungan yang ada -- belajar dari kasus bank konvensional. Secara rinci, kelemahan dan keunggulan bank Islam adalah sbb:

a. Kelemahan adalah $:^{29)}$

- Bank terlalu berprasangka baik kepada semua nasabahnya dan berasumsi bahwa semua orang yang terlibat dalam bank Islam adalah jujur. Sehingga, sangat rawan dan perlu usaha tambahan untuk mengawasi nasabah.

- Sistem bagi-hasil memerlukan perhitungan-perhitungan yang. rumit terutama dalam menghitung bagian laba nasabah yang kecil-kecil, yang nilai simpanannya di bank tidak tetap.

- Karena bank ini membawa missi bagi hasil yang adil, maka bank Islam memerlukan tenaga profesional yang andal dari pada bank konvensional.

\section{b. Keunggulan adalah $;^{30)}$}

- Kuatnya ikatan emosional keagamaan antara pemegang saham, penengelola, dan nasabahnya, yang dapat dikembangkan kemudian menjadi kebersamaan menghadapi resiko dan membagi keuntungan secara adil.

- Semua pihak yang terlibat dalam bank Islam akan berusaha sebaik-baiknya sebagai pengamalan ajaran agama, sehingga berapapun hasil yang diperoleh ditakini membawa berkah.

- Adanya fasilitas pembiayaan yang tidak membebani nasabah sejak awal dengan kewajiban membayar biaya secara tetap.

\section{6) Ibid, hal, 34-35.}

27) Nejatullah, Op.Cit., hal. 34-35.

28) John J. Donohue - John L. Esposito, ed., Islam dan Pembahanian, Ensiklopedi. Masalah-Masalah, terjemah. Machnun Husein, Rajawali, Jakarta, 1984, hal. 398.

29) Karnaen, Op.Cit., hal. 46.

30) Ibid, hal. 47-48. 
Tidak ada diskriminasi terhadap nasabah yang didasarkan atas kemampuan ekonominya sehingga aksesibilitas Bank Islam menjadi sangat luas.

- Bagi penyimpan dana tersedia peringatan dini tentang keadaan banknya yang bisa diketahui sewaktu-waktu dari naik-turunnya jumlah bagi hasil yang diterima.

- Fasilitas pembiayaan yang lebih mengutamakan kelayakan usaha dari pada jaminan.

- Cost push inflation yang ditimbulkan oleh perbankan sistem bunga dihapus sama sekali.

- Bank Islam lebih mandiri dari pengaruh gejolak moneter baik dari dalam amupun dan luar negeri.

- Persaingan antar bank Islam ditentukan oleh keberhasilan dalam membina nasabah.

- Tersedianya kredit kebajikan (al-qardhul hasan), yang tidak mungkin di dapat di bank konvensional.

Di samping itu Mannan mengajukan sebuah analisis kenapa bank bebas bunga akan lebih baik dibandingkan sistem bunga. Ada beberapa elemen yangbisa membuktikan itu, di antara yang cukup penting adalah bahwa; bungalah yang menyebabkan pertumbuhan kapitalis di masysrakat, tabungan atau investasi tidak dapat dimobilisir dengan rangsangan bunga (ingat analisa keynes), sistem bunga lebih menimbulkan pengangguran dari pada sistem non bunga. Bunga bisa mendorong pada depressi ekonomi, serta bunga lebih berpengaruh negatifbagi perdamaian dunia. ${ }^{31)}$

Melihat itu semua, maka perbankan Islam punya peluang besar untuk berkembang di Indonesia di mana jumlah umat Islam sangat besar, bahkan paling besar bila dibandingkan dengan jumlah muslim di negara Islam manapun juga, sebagaimana appendiks yang disodorkan oleh Ziauddin Sardar. ${ }^{32)}$ Terlebih pendekatan normatif (seperti: Islam - non
Islam/kafir, dosa-pahal, halal-haram) sangat besar pengaruhnya, bisa berfungsi sebagai rallying-point untuk memobilisasi umat. ${ }^{33)}$

\section{Antisipasi Yuridis.}

Melihat perkembangan perbankan Islam di Indonesia yang memiliki akses begitu besar dalam pangsa pasar, maka dengan tanpa pretensi lain kita bisa mengatakan sistem ini memiliki prospek yang cukup cerah.

Namun, kehadirannya akan mencuatkan sebuah problem baru bila tidak diikuti dengan kesiapan konstelasi yuridis. Sehingga perlu upaya antisipasi sedini mungkin atas kehadirannya, yaitu dengan memberikan perundang-undangan yang jelas.

Kita lihat saja, bagaimana produk-produk paket yang ditawarkan oleh bank-bank Syari'ah (termasuk yang di dalamnya BPR Syari'ah), meski sebagian sama dengan produk bank konvensional, namun secara garis besar menampakkan perbedaan, karena memang secara prinsipal keduanya mempunyai grand-rule yang tidak sama.

Undang-undang Perbankan yang telah ada, sebagaimana kita maklumi, adalah dibuat dengan mengacu pada bank-bank sistem bunga. Maka logis saja kalau ada haI-hal tertentu pada bank Syari'ah yang tidak bisa dirujukan (tidak tertampung) pada perundang-undangan yang telah ada.

Diantara hal-hal yang bisa dijadikan pertimbangan untuk antisipasi yuridis adalah sbb:

31) Manan, Op.Cit., hal. 126-134.

32) Ziaudin Sardar, Reakayasa Masa Depan Peradaban Muslim, terjemah, Rahmani Astuti, cet. 1, Mizan, Bandung, 1986, hal. appendiks.

33) Lihat analisis Dr. Kuntowidjojo, dalam Prisma No. 5, Th. XVII, 1988, hal.79. 
- Perlu dimasukkannya beberapa istilah bank Syari'ah ke dalam ketentuan umum undang-undang Perbankan. Ini sangat penting, mengingat, kelembagaab yang ada dalam bank Syari'ah serta produkproduk yang ditawarkannya sebagian besar sama sekali baru dan belum didapatkan dalam perundang-undangan yang telah ada. ${ }^{34)}$

- Sejauh mana Otoritas dari Dewan Pengawas Syari'ah dan Liason Syari'ah yang ada. Keduanya, dalam tata organisasi bank Islam merupakan posisi yang sangat essensial dalam menentukan kebijakan, mengakibatkan penentuan prosentase bagi hasil secara vulgar dan bebas, yang ini sangat menentukan tingkat keuntungan yang akan diperoleh - bank, yang selanjutnya menentukan defisit tidaknya bank.

- Perlu adanya ketentuan lebih lanjut sehubungan dengan produk pengerahan dana bank Syari'ah yang berasal dari zakat, infak, shadaqah (ZIS). Bagaimana Modus penyerahan dan penyalurannya kepada mereka yang berhak menerimanya. Serta bagaimana optimalisasi perannya.

\section{"Harus disadari memang bahwa ada kelemahan-kelamahan tertentu dalam Bank Islam namun kelemahan-kelemahan itu menjadi tidak begitu berarti dan tidak krusial bila dikomparasikan dengan keuntungan yang ada."}

sehingga, di tangan biro inilah kompetensi untuk menentukan sesuatu dan tidaknya kebijakan yang dilahirkan dengan konsep syari'ah. Maka perlu adanya perundangundangan yang jelas untuk pertanggungjawabannya, meskipun diatas dewan tersebut telah ada MUI dan $\mathrm{BI}$, atau bahkan pada level internasional telah terbentuk konsorsium yang bernama The Higher Shariah Supervisory Council. Ini penting menyangkut kebijakan syar'i yang dilakukan.

- Perlu adanya kerangka perundang-undangan yang mampu memberikan standardiśasi dalam ketentuan bagi hasil. hal ini sangat penting untuk membatasi oknum bank Syari'ah agar tidak menjalin kolusi dengan pihak-pihak tertentu yang bisa
Itulah di anatara hal-hal yang menjadi perlunya upaya antisipasi yuridis atas menggejalanya perbankan Islam di Indonesia dengan prospek sebagaimana telah di gambarkan dimuka. Antisipasi ini dirasa penting untuk menghindari masalah-masalah yang sangat mungkin untuk timbul.

\section{Biodata}

a Drs. Agus Triyanta, adalah staf pengajar FH-UII dan redaktur Jurnal Hukum FH-UII. Alumnus IAIN Sunan Kalijaga Yogyakarta.

33) Lihat: UU No. 7 Th. 1992, Op.Cit. 